 \\ Erratum}

https://doi.org/10.11646/zootaxa.4991.3.11

http://zoobank.org/urn:lsid:zoobank.org:pub:A91EC1AC-20B9-46E7-9A6A-E4B59645D96F

\title{
RODRIGO ROUCOURT CEZÁRIO \& RHAINER GUILLERMO-FERREIRA (2021) Heteragrion gorbi sp. nov. (Odonata: Heteragrionidae) from southeastern Brazil. Zootaxa, 4965: 078-086.
}

The authors provided the incorrect date for the new species name. The scientific description of Heteragrion gorbi sp. nov., although written in 2020, was only published on 27 April 2021. Therefore, following the recommendations of the current International Code of Zoological Nomenclature (ICZN 1999), on p. 79 readers must consider Heteragrion gorbi sp. nov. Cezário \& Guillermo-Ferreira, 2021, instead of Heteragrion gorbi sp. nov. Cezário \& Guillermo-Ferreira, 2020. 